Survey, opened the discussion, and regretted that, though he had enjoyed the advantage of seeing the large collection of specimens made by the Duke of Argyll from the Inveraray quartzite, ard also of examining the rock in situ, he was still unconvinced that the markings were really of organic origin. It was possible, he thought, to trace a series of stages from single crystals or irregular groups of crystals of pyrites through variously shaped aggregates into the "ovate bodies" of the Duke. In the more solid, massive, and uncrushed portions of the quartzite, these aggregates could be seen quite fresh, and probably not far from their original shape. But wherever the rock had undergone shearing (and this was the case throughout most of its mass), its component particles had been drawn out in the direction of movement, the original irregular, rounded or egg-shaped aggregates of sulphide of iron had been flattened and elongated, becoming eventually mere strips that run parallel to each other. The trend of these strips exactly coincided with that of the long axes of the foliation-minerals in the surrounding rocks, and were regarded by Mr. Geikie as pointing to the results of shearing in the rock-mass and not to the burrowings of worms. The ferruginous rings seemed to him to be due to an oxidation and leaching out of the pyritous matter of the little mineral aggregates, as so often happens among the Carboniferous and Jurassic sandstones that contain ferruginous concretions. While he could not admit that the markings in the quartzite of Inveraray had yet been shown to be of organic origin, he thought it quite possible that the precipitation of the iron-disulphide had originally taken place in presence of decomposing organic matter, as in many blue muds of the present day, and that portions of such pyritous mud had been drifted into the sandy deposit which is now quartzite.

Mr. B. N. Peach, of the Geological Survey, was also unable to recognize organic forms among the Inveraray markings. He thought that the parallelism of these markings where they were most elongated, and their coincidence with the general line of shearing movement in the rock, cast doubt upon their having any connection with worm-burrows.

Mr. Murray, of the Challenger Expedition, who thinks that sandstone deposits generally are sub-aërial formations, was disposed to refer the so-called annelid tubes of the Sutherland quartzite not to the borings of marine worms, but to the remains of terrestrial plants that grew upon sand-dunes.

In a paper which followed this discussion, Mr. Geikie gave an account of the evidence supplied by the rocks of the Highlands of remarkable deformation by mechanical movements. Illustrating his remarks by a large series of specimens, he showed how the Cambrian conglomerate of Assynt had its pebbles of quartz drawn out and its original sandy mud converted into a fine micaceous schist; how the conglomerates of the Central Highlands had their quartz-pebbles flattened like buttons and drawn out in the direction of movement, while their envelope of original sand and mud had been changed into a quartzschist ; how the granular quartzite of Sutherland had been crushed and rolled out into a thoroughly schistose mass ; how the coarse Archæan pegmatites had been likewise crushed down until their material had, as it were, flowed onwards so as now to show a close parallel to the "fluxionstructure " of many porphyries, and even to assume a finely laminated or shaly structure,'and lastly, how the highly crystalline basic dykes of the most ancient gneiss of the northwest had been sheared and rearranged until they passed into the most perfect forms of sericite-schist. He adverted to the obviously sedimentary origin of the great mass of the rocks constituting the Highlands east of the line of the Great Glen, and mentioned that the recent work of the Geological Survey in tracing the great belt of limestones from the coast of Banffshire through the Grampians into Argyllshire afforded now a good horizon, from which it might be hoped the general structure of the Highlands might be worked out. He exhibited specimens of quartzite from Perthshire and other districts containing various markings, some of which there could be little doubt were of organic origin. He also showed a singularly interesting series of specimens which he had recently received from Dr. Reusch, of the Geological Survey of Norway, displaying recognizable trilobites and corals embedded in a finely crumpled micaceous schist, exactly similar in character to much of the schist that constitutes wide regions in the Scottish Highlands. These specimens afforded much encouragement to search for fossils in the calcareouswand ferruginous layers and concretions that occur so frequently among our finer mica-schists and phyllites.

\section{THE LAW OF STORMS IN CHINA.}

THE law of storms in Hong Kong was investigated by aid of the lithographed paths of the typhoons in I 884 and 1885 , published in "Observations and Researches made in 1886 " and in those of 1885 and 1887 now in course of publication. Only those within 300 miles of the Observatory were considered in this connection. The angles between the wind and the radius vector, i.e. the line joining the Observatory with the centre of the typhoon, were measured and mean values derived, and the same was done for Victoria Peak (I 8 I 6 feet above the sea) and for the lower clouds.

No connection could in any case be traced between the distance from the centre and the direction of the wind, but the latter depends upon the bearing of the centre. As pointed out in "The Law of Storms in the Eastern Seas" (NATURE, vol. xxxv. p. I36), and elsewhere, the wind has a tendency to blow along the southern coast of China when a typhoon is raging in the China Sea, so that the wind in such cases veers only about half as much while the typhoon moves westward as in other cases, and this is the reason why the angle between the wind and the radius vector is larger than usual when the centre is situated to the south of Hong Kong.

When there is a typhoon anywhere between north and east within 300 miles of the colony-which, however, is not common - the wind at the Peak (about north-northwest) blows away from the centre - much more so than the clouds, which in fact describe almost a circle round the centre in that case; and this remarkable feature or something very like it has been found to obtain also at Ben Nevis with the centre of a depression in the north-e.st.

The angle between the wind and the radius vector is, at the Observatory, $8 i^{\circ}$ north of the centre, $55^{\circ}$ to the west, $56^{\circ}$ to the south, and $58^{\circ}$ to the east. At the Peak, it is $91^{\circ}$ to the north, $87^{\circ}$ to the west, $81^{\circ}$ to the south, and $78^{\circ}$ to the east. At the level of the lower clouds, it is $92^{\circ}$ to the north, $85^{\circ}$ to the west, $67^{\circ}$ to the south, and $86^{\circ}$ to the east.

The observations made at South Cape (Formosa) were treated similarly, with the following result: to the north of the centre the angle was $50^{\circ}$, to the west $50^{\circ}$, to the south $64^{\circ}$, and to the east $47^{\circ}$.

The angle observed on board ship in the China Sea in typhoons-say in about $16^{\circ}$ N. lat.--is on an average $47^{\circ}$, as previously published; at South Cape $\left(22^{\circ} \mathrm{N}\right.$. lat., the same as Hong Kong) $54^{\circ}$; at Hong Kong $62^{\circ}$; at Victoria Peak, above Hong Kong, $84^{\circ}$; and at the level of the lower clouds $82^{\circ}$. The angle previously obtained from observations made on board ship, and also at coast stations in about $32^{\circ} \mathrm{N}$. lat., was $75^{\circ}$ on an average, but so far north it seems to be more variable than in the China Sea, where it has been found remarkably constant, between (say) $12^{\circ} \mathrm{N}$. and $20^{\circ} \mathrm{N}$. But from the figures given it is seen that the angle increases with the latitude and with elevation above sea-level. The woodcut represents a typhoon in the neighbourhood of Hong Kong, or rather 
a mean of those observed during the four years. The diameter of the circle is 600 miles.

The average force of the wind according to Beaufort's scale (o-12), at various distances from the centre, expressed in nautical miles, is shown in the following table, but owing to the typhoons differing so much in size the figures representing the mean values are often widely different from the values obtained from observations made in a particular typhoon. That is not the case with the direction of the wind, which depends upon the bearing but not upon the distance from the centre or the size of a typhoon.

\begin{tabular}{ccccccccc} 
Distance. & \multicolumn{3}{c}{ Observatory. } & Peak. & \multicolumn{2}{c}{ South Cape. } & \multicolumn{2}{r}{ China Sea. } \\
60 & $\ldots$ & 8 & $\ldots$ & 9 & $\ldots$ & 9 & $\ldots$ & I I \\
160 & $\ldots$ & 5 & $\ldots$ & 6 & $\ldots$ & 6 & $\ldots$ & - \\
250 & $\ldots$ & 4 & $\ldots$ & 5 & $\ldots$ & 4 & $\ldots$ & 6
\end{tabular}

This table proves the wind to be strongest over the open sea, and also, though to a less extent, at some height above sea-level. The force of the wind increases at a greater rate on approaching the centre at sea, and that is to a certain extent likewise the case at South Cape, which is far from the mainland and soon reached by typhoons arriving fresh from the Pacific Ocean, where most typhoons originate, although some of them are formed to the westward of the Southern Philippines.

The force of the wind is much greater behind the centre than in the anterior semicircle both at sea and on shore, and the consequence is that the strongest blow is not experienced till the barometer begins to rise. For instance, at an average distance of about 160 miles, the mean force in Hong Kong is 7 to the north, 3 to the west, 6 to the south, and 5 to the east. At South Cape (Formosa) it is 6 to the nortb, 5 to the west, 7 to the south, and 6 to the east. To the north of a typhoon the wind is remarkably fresh along the southern coast of China, even when the centre is over 300 miles away. It makes an

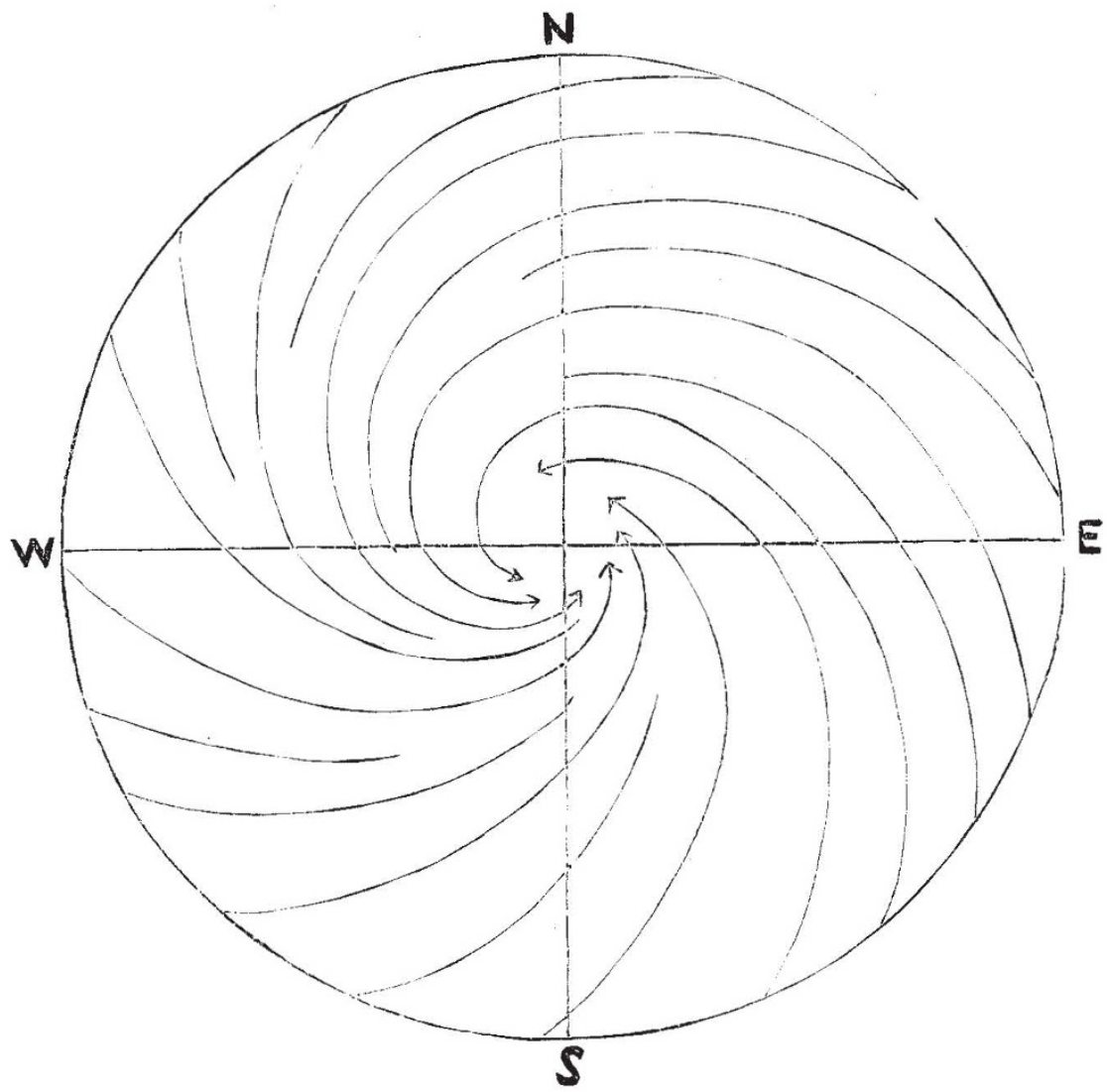

A Typhoon in Hong Kong.

impression as if the trade-wind was blowing in the middle of summer, while a typhoon moves westward in the China Sea. In So:thern Formosa, where typhoons moving north-westward predominate both in number and in intensity, the wind is strongest to the south or southeast of the centre.

At Victoria Peak the force of the wind does not depend upon the bearing of the centre, or at any rate only slightly so. It follows that the wind-force registered there just before the approach of a typhoon considerably exceeds that registered at the Observatory. The difference in force is only about one on Beaufort's scale, when the centre is north or west of the colony, and while the centre is situated to the southward it ustally blows harder at sea-level than on top of the Peak.
W. DOBERCK.

\section{THE STATE OF VESUVIUS}

THE "Note" in NATURE (p. I84) on the state of the Vesuvian volcano has been copied by many newspapers, and I have received a number of letters asking for further information. To satisfy this desire, I give the following particulars as to what occurred subsequent to December 15,1888 , and to the information above mentioned.

During the remainder of the month of December, the vent was extremely active, ranging from the second to the fourth degree of activity, so that the cone of eruption was often quite red, after a burst, from the large number of lava cakes falling on its sides. This constant ejection of fragments of red-hot pasty lava rapidly increased the 